\title{
Socio-Economic Factors in Measuring the Demand for Residential Neighbourhood in Nigeria
}

\author{
Babatunde Femi Akinyode ${ }^{1}$, Tareef Hayat $\operatorname{Khan}^{1}$ \& Abdullah Sani Bin Hj Ahmad ${ }^{1}$ \\ ${ }^{1}$ Faculty of Built Environment, Universiti Teknologi Malaysia, Malaysia \\ Correspondence: Tareef Hayat Khan, Faculty of Built Environment, Universiti Teknologi Malaysia, Malaysia. \\ Tel: 60106669717. E-mail: tareef@utm.my
}

Received: December 14, 2014

doi:10.5539/ass.v11n12p235
Accepted: January 22, 2015 Online Published: April 30, 2015

URL: http://dx.doi.org/10.5539/ass.v11n12p235

\begin{abstract}
Socio-economic factor plays an important role in housing decision making through which demand for housing types and residential neighbourhood are made. This study aims at examining the relationship between socio-economic factors and the demand for residential neighbourhood in Nigeria within the context of Ibadan urban cenre. The study utilised the quantitative and qualitative methods. Quantitative approach was employed by the administration of questionnaire among 494 respondents while the qualitative aspect dealt with direct interviews through the use of unstructured questionnaire among 27 participants. Correlation, regression and content analyses were used to evaluate the results of the methods. The findings revealed that, these factors have a great influence on the social status of housing consumers and affect their demand for residential neighbourhood. In conclusion, the demand for residential neighbourhood in Ibadan urban centre has the potential to be explained by the socio-economic status such as; educational level, employment status, official status and monthly income of housing consumers.
\end{abstract}

Keywords: demand, Ibadan, residential, socio-economics, urban centres

\section{Introduction}

Socio-economic status of an individual can be used to explain household economic inequality which reflects his/her class, status and economic position in the society and play an important role in enhancing individual household and the whole of the society wellbeing. When searching for residential apartments, individuals and households consider two major criteria namely; the type of housing and the type of residential environment. The demand made by a particular household is guided by social life style and restricted by income and opportunities offered by the housing market (Yosef, 2005).

Housing is considered to be one of the basic necessities of life as it has a profound impact on health, welfare and productivity of individuals (Akintunde, 2008; Agbola \& Kassim, 2007). In recent years, housing is not only considered purely as shelter but as a lifestyle which encompasses economic, social and educational needs (Ademiluyi, 2010). It must be able to meet the need and aspiration of the residents as well as contribute to the physical, mental, social wellbeing of the people and provide maximum quiet environment, living and outdoor spaces, privacy, cleanliness, safety and aesthetic satisfaction (Okechukwu, 2009; Israel \& Bashiru, 2008; Agbola \& Kassim, 2007; ÆrØ, 2006; Olayiwola et al., 2005).

Different individuals make residential demand based on their lifestyle which implies that persons may prefer an area because of the culture or lifestyle it projects $(Æ r \oslash, 2006)$. Winstanley et al. (2002) argued that "while relevant factors can be isolated and probably ranked in importance to households, it is interconnections between the different factors that shape individual and household decisions". Tatu's (2010) study in Dar es Salaam in Tanzania explored the factors urban residents consider when making residential location decisions. The study reveals that someone's decision to move to an area to live involves thinking about the costs, influence of the location on livelihood, accessibility to public services, shops and school as well as the safety and wellbeing of the family together with whom the neighbours would be (Tatu, 2010).

The aim of this study is to explore the worth and effect of socio-economic factors in the prediction of residential neighbourhood demand in Nigerian urban centre. The research question to achieve this centred on to what extent the demand for residential neighbourhood can be predicted by socio-economic factors. Correlation and 
regression analysis were drawn between the housing density and socio-economic factors. The predictors of the demand for the residential neighbourhood were the socio-economic and demographic variables of the sampled respondents.

\section{The Study Area}

Ibadan is the capital city and administrative headquarters of Oyo state, Nigeria. It is the largest indigenous city in Africa, south of Sahara desert. According to 1963 national census figures, Ibadan was the most populous city in Oyo state with a population of 627,379 (National Population Commission-NPC, 1963). The population of Ibadan reached 1, 835, 302 in 1991 (NPC, 1991) with population percentage increase of 65.82 between 1963 and 1991. Ibadan has reached a population of 2, 559, 853 comprises of eleven local government areas which is 75.49 percentage increase to 1963 population figures and 28.30 percentage increase to 1991 population figures (NPC, 2006). The 2015 and 2020 population of Ibadan was projected using 2006 population at $3 \%$ annual population growth rate (NPC, 2006). The formula for the calculation for the population projection was $\mathrm{Pn}=\mathrm{Po}(1+\mathrm{r} / 100)^{\mathrm{n}}$ where ' $\mathrm{Pn}$ ' is the projected population for the target year, ' $\mathrm{Po}$ ' is the base year population (2006), ' $\mathrm{r}$ ' is the annual growth rate and ' $n$ ' is the year interval between the base year and the year to be projected (Mehta, A.C, 1997). The projected 2015 and 2020 Ibadan population are 3, 340, 028 and 3, 872, 007 with $23.36 \%$ and $33.89 \%$ increase percentage respectively. The history of Ibadan has many versions to it, but it is generally agreed that there are "three Ibadans". The first Ibadan was formed by Lagelu, an Ife warrior and farmer. The first camp, originally known as "Eba-Odan" which means "by the field" that is, in between the forest and savanah (Ayeni, 1994). The settlement finally grew up to a large settlement and later on, the name changed to "Eba-Odan" and finally changed to Ibadan.

The settlement of the first Ibadan did not last for long and it was destroyed by the Olowu because Ibadan treated Egungun mystery with levity and disdain. This obliged Lagelu to escape with his family and settle at Eleyele hill where the second Ibadan was founded. Lagelu and his people suffered many hardships on this hill and had to feed on snails and on a wild apple called "Oro" which were both found on the hill. Hence, the cognomen of Ibadan says "Ibadan omo a'joro sun, omo aje'gbin yo, omo afi 'karahun fo'ri mu". This means Ibadan people are the people who eat "Oro" for supper, feed on snails and use the shells as bowls for taking corn porridge (Ayeni, 1994). Other people from many parts of Yorubaland joined Lagelu and people on the hill. They grew prosperous and multiplied to the extent that the hill could no longer accommodate them. As a result of this situation, they had to move to the present site which is the "third Ibadan". Ibadan is a nodal nerve centre on which major routes and commercial activities converge. The majority of the area is formed of banded gneisses with significant instances of schifts and quartzites (Tomori, 2007; Aweto, 1994).

\section{Literature Review}

The socio-economic factors are the product of several key issues in housing. They are discussed in the following section.

\subsection{Effects of Urbanisation on Housing}

Since 1960s, people began to shift their living to cities. According to Glaeser, Kolko and Saiz, (2001), between 1960 and 1990 the growth rate of movement of household into the city increased whereas the growth rate within the suburbs areas fell. Despite adequate housing is crucial for effective performance of man, a considerable proportion of Nigerian population live in sub-standard and poor housing as well as in deplorable unsanitary residential environments (Onibokun, 1985). The prevailing housing problems in Nigeria include acute housing shortage, overcrowding, unsanitary living conditions, exorbitant rent relative to income, the exploitative tendency of shylock landlords, poor and inadequate social amenities, the high rate of homelessness especially in the urban areas and the high rate of substandard housing both in the rural and urban areas (Agbola, 1998). Many Nigerians especially the newly formed households are unable to afford the lowest priced house in the formal sector housing market thereby leading them to either share with relatives or seek the habitation within the informal extra-legal housing sector within the urban centres (Ikejiofor, 1998; Hoek-Smit \& Diamond, 2003).

The government had to consequently intervene, promulgating laws to control, to some extent, the operating forces in the housing sector to bring housing to the reach of a large proportion of the populace (Olatubara, 2007). This ushered in the issue of housing policy with aim of achieving the objectives of obtaining the optimal use of existing housing resources to ensure adequate housing for all households, guide the location of new housing, be responsible for the housing needs of special people and to influence the policies of public authorities in allocating housing (Olatubara, 2007). The effects of urbanisation on housing resulted to high housing demand. 


\subsubsection{Housing Demand}

Housing demand can be explained as the willingness and ability of housing consumer to pay for a particular dwelling depending upon such consumer's incomes, house type, location preferences and local prices (Welsh, 2002) at a particular given time period. The main determinant of the housing demand is household composition while other factors include consumer's income, housing price, cost and availability of credit, consumer preferences or taste and investor preferences (Olatubara, 2007). Housing supply is produced using land, labour and various inputs such as electricity and housing materials. The quantity of the new supply is determined by the cost of these inputs, the price of the existing stock of houses and the technology of production.

The time of housing process, materials cost of housing, unbearable conditions on getting loan from the mortgage banks and government policies have been factors militating against the achievement of the effort of public developers and private developers in bridging the gap between housing supply and demand (Israel and Basiru, 2008). Housing demands enhanced with increase in urban population thereby affected housing availability (Okechukwu, 2009; Agbola \& Adegoke, 2007; Tipple, 2001).

Demands for a particular location led to increase in the price of land in that location (Todd, 2007). Naturally, house rents within cities and towns, where there are better amenities and physical conditions command higher financial value (Roback, 1982). Housing supply does not only reflect the ability to build; it also represents the historical stock of the past construction (Edward, 2010). High demand for housing in Ibadan urban centre consequently led to increase in land value.

\subsubsection{Land Value}

Demand for land within the urban centre will increase and enhance more value whereas its impact would be reduced with low demand for land in the rural area (Edward, 2010; Glaeser \& Ward, 2009; Nelson et al., 2007; Jun, 2006). It can therefore be deduced that high demand for land has a direct correlation relationship with high rise in land price and vice-versa. Other factors such as economic factors, infrastructure provision and consumer preferences had influence on land price. Availability of basic amenities or easy accessibility to urban facilities and services within urban centres has great influence on the land price (Gurran et al., 2008).

Regulatory measures, high continuous demand for housing, purchasing power, population and economic growth led to limited supply of urban land (DSE, 2003; Birrell \& Healy, 2003; Birrell et al., 2005). Others factors include flexible lending policies, housing subsidies and Unlimited Urban Growth Boundaries (UGB). They also contributed greatly to the rise in land value and construction price which eventually affect the housing supply.

The promulgation of the 1978 land use decree was meant to solve the problems of unsmooth, fraudulent practices and costly transfer of land to two or more different people (Agbola, 1987) through which the entire land within a state is invested into the hands of state governors to hold in trust for the people in the state. It is expected of prospective home owners to apply for the use of the land at a reasonable price. However, the implementation of this decree was faulty and has not achieved its aim but contributed to the inadequate and unaffordable housing in most of our urban centres (Arimah, 1997; Agbola, 1987).

Adoption of the national sites and services program by increasing supply of serviced plots at affordable cost in 1986 by Federal Government as strategies for housing delivery (Onu \& Onu, 2012) was mainly to create easy access to land to enhance home ownership. The goals of the programme were to provide serviced land for housing development and commercial activities in a well decent and planned environment to eliminate obstacles to housing supply and provide solutions to private and public sectors as well as individual in housing delivery system. However, only about 20, 000 plots were allocated in about 20 states of the federation since the commencement of the program in 1986 (Onu \& Onu, 2012; Ajanlekoko, 2001). As a result of increase in land value in Ibadan urban centre which made the land price to be too high necessitates transaction between the land owners and the prospective buyers.

\subsubsection{Housing Transaction Costs}

Quigley (2003) submits that housing attracts high transaction costs relating to its exchange, in terms of searching. These transaction costs include legal and adjustment costs. Housing speculations led to price increase of housing (Gregory et al., 2009). When the residential housing in an area is commercialised, there will be intermediary between the housing producer and housing consumer which will lead to the increase in housing price. The interaction between the housing producer and consumer are seen with the prices being offered by the consumers and the price being agreed by the producers before a final transaction is made (Ursula, 2002).

Agbola and Adegoke (2007) considered housing as an expensive economic product which requires large capital outlay. Housing production has always been posing problems to majority of Nigerians due to unequal 
distribution of income. In the study conducted in Makurdi metropolis, Benue state in Nigeria by Onu and Onu (2012), they looked at the challenges confronting low income earners in urban residential housing areas and discovered that more than half of their respondents (57.8\%) earn less than N10, 000.00 (US\$62.50) a month which made it difficult for them to afford decent house. They were of opinion that carefully planned land for low income housing should be allocated to the low income earners.

\subsection{Household Socio-Economic Status}

Household plays a significant role in decision making and its economics status determines household level of living standard. Household economic status, social status, education, official status, marital status, nativity and years of being in Ibadan can be used to analyse inequality in economic status among different households. Family socio-economic status describes family's position, rank, class, status or economic position in a society (Mehdi et al., 2009). This is based upon the concepts of allocating scarce and limited resources to various activities that are related with the progress, protection and conservation (Mehdi et al., 2009).

Chuma and Molyneux (2009) discovered differences between rural and urban family economic status classification using expenditure and asset indices. Household management helps individuals and families to improve their quality of life through effective decision making (Key \& Firebaugh, 1989). Consumer's cultural and social life with the behaviour of investor play an important role in the development of residential lofts according to Zukin's (1988) examination of loft living in New York. In New York, poor people live disproportionately in central cities because of their socio-economic status and they can survive without having a car (Glaeser, Kahn, \& Rappaport, 2008). Immobility of housing contributes to the shortage of housing supply in our urban centres (Okechukwu, 2009).

Okechukwu (2009) argued that; "the filtering process is another market solution that could ensure the gradual release of adequate housing for lower income households by the move of the affluence households when they vacate their housing for their better and befitting ones". If the market is responding towards meeting the housing need of the high income class through the provision of more decent and costly housing unit, there would later be movement of the whole classes of people of both low and middle income groups moving into better and more decent housing. This will however depends on housing affordability.

\subsubsection{Housing Affordability}

Housing affordability is an issue to be considered in housing supply and demand. The word afford can be defined as being able to pay without incurring financial difficulties (Collins Dictionary). New Zealand Institute of Economic Research (2005) defined Housing affordability as a difficult matter of housing costs and income levels but it entails people's ability to obtain housing and to stay in it. Household's income, taste and price of housing are parts of determinants that need to be considered if housing is going to be affordable by the prospective housing consumer (Olatubara, 2007).

The chartered Institute of Housing (1992) as quoted in Onu and Onu (2012) identifies rent levels, household income and eligibility of households for housing benefits to determine whether accommodation is affordable or not. In the United States and Canada, a commonly accepted guideline for housing affordability is housing cost that does not exceed $30 \%$ of a household's gross income (Onu, 2012). When the monthly carrying costs of a home exceed $30.35 \%$ of household income, the housing is considered unaffordable for that household.

\subsection{Summary}

Since migration is a consequential effect of urbanisation and money plays a big role in housing, several socio-economic variables can act as predictors to housing demand and residential neighbourhood. For the purpose of achieving the aim of this study, density of the residential neighbourhood has being identified as the dependent variables while the socio-economic factors of the respondents such as marital status, income earning group, educational level, employment status, official status, respondent's nativity, estimated monthly income and years living in Ibadan as the independent variables i.e. they are the predictors.

\section{Method}

This study utilized extensive quantitative and qualitative research methods. Quantitative approaches were employed through the administration of questionnaire among 494 respondents. The questions within the questionnaire included demographic, socioeconomic questions that related to the respondents' households and the demand for their residential neighbourhood. 


\subsection{Sampling Techniques}

The study employs stratified conditional random sampling. This is the technique of sampling through which the probability of a unit of a population being sampled depends on the values of the exploratory variables that can lead to consistent and efficient estimates (Guido \& Tony, 1996). The study focussed on five local government areas within Ibadan urban centre. Each of the local government areas is sub-divided into political wards and each of the political wards is sub-divided into unit count area. The unit count areas were also identified according to the low, medium and high density areas. The number of political unit count area determined the number of administered questionnaires in each of the political wards.

\subsection{Participants}

Two sets of participants included those that were involved in direct interview with unstructured questionnaire and the general public that constituted the households or housing consumers within the five local government areas. The first set of participants were 27 comprising of 5 Directors of Town planning from the 5 local planning authorities, 2 landlord association chairmen, 4 professional town planners, 3 architects, 4 Estate surveyors, 1 bricklayer, 3 carpenters and 5 iron benders. The second set of the participants include 500 respondents within the five local government areas. There were 112 respondents in Ibadan North, 118 respondents in North-East, 57 respondents in North-West, 99 respondents in South-East and 106 respondents in South-West while the remaining 8 respondents served as extra. Through verification of the questionnaires, 6 questionnaires were found incomplete and discarded, remaining 494 questionnaires representing 494 respondents were used in this study.

\subsection{Overview of Procedures}

At the beginning of this study, 6 enumerators were recruited and trained for the administration of questionnaire. During the training, the author asked the recruited enumerators to demonstrate the administration of questionnaire. This is to see if they really understand the content of the questionnaire to ensure the accurate interpretation of the content and the language of the questionnaire. The performance of the enumerators indicated that they have really understood the content and interpretation of the questionnaire language. The author then assigned all the 6 recruited enumerators to go to the field for the administration of the questionnaires. The administration of the questionnaires was done taking each of the local government one after the other. The interview aspect of the research through semi structured questionnaires was undertaken by the author himself to have accurate knowledge and better understanding of the housing situation in the study area as it relates to the subject matter.

\subsection{The Questionnaires}

The questionnaire consisted of three sections. Section A is on socio-economic/household survey. It comprised of 17 questions that captured the demographic information of the respondents and socio-economic variables such as sex, age, marital status, income earning group, religion affiliation, educational level, employment status, official status, respondent's nativity, estimated monthly income and years living in Ibadan. Section B is on housing characteristics, housing quality, utilities and amenities. The section is categorised into four parts as housing tenure, construction material of the house, housing utilities and amenities and lastly the house rent. Section C focuses on respondent's evaluation on the house as it relates to house rent, reasons for high house rent, reasons for house preferment, reasons for unsatisfied house, housing condition and characteristics, land price, house demand factors, and planning policy. The sections A and B are closed ended questions with different number of options while the section $\mathrm{C}$ was designed based on 5 points Likert scale format. Demographic and socio-economic variables were recorded in the questionnaire because they are assumed to be the predictors (independent variables) of the demand for residential neighbourhood (dependent variables). The socio-economic and demographic variables are shown in Table 1 to presents their means and standard deviations.

\subsection{Verification of the Enumerators' Accuracy}

Table 1. The socio-economic and demographic characteristics variables of the respondents

\begin{tabular}{|c|c|c|c|c|c|c|c|c|c|}
\hline & $\begin{array}{c}\text { Respondent } \\
\text { Age }\end{array}$ & $\begin{array}{c}\text { s Marital } \\
\text { Status }\end{array}$ & $\begin{array}{l}\text { Employment } \\
\text { Status }\end{array}$ & $\begin{array}{l}\text { Official } \\
\text { status }\end{array}$ & $\begin{array}{l}\text { Estimated } \\
\text { Monthly } \\
\text { Income }\end{array}$ & $\begin{array}{c}\text { Respondent' } \\
\text { Native }\end{array}$ & $\begin{array}{l}\text { Years in } \\
\text { Ibadan }\end{array}$ & $\begin{array}{l}\text { n Educational } \\
\text { Level }\end{array}$ & $\begin{array}{l}\text { Income } \\
\text { Earners }\end{array}$ \\
\hline Mean & 3.39 & 2.14 & 2.35 & .35 & 2.33 & 1.43 & 5.36 & 2.10 & 1.17 \\
\hline $\begin{array}{c}\text { Std. } \\
\text { Deviation }\end{array}$ & 1.182 & 1.067 & .903 & .724 & 1.216 & .496 & 1.137 & .600 & .486 \\
\hline
\end{tabular}

Source: Author's Survey, 2014 
All enumerators were checked for the accuracy in the administration of questionnaires. This was achieved by asking the enumerators to submit the administered questionnaires second day before its commencement. This enabled the authors to observe if there was any mistake in any of the administered questionnaires. Subseqently, the concerned enumerators were asked to return to the field and re-administer the questionnaire where errors were noticed. To further ensure the accuracy of the work, the authors apart from checking the enumerators on field occasionally without giving any notice, participated in the administration of the questionnaires.

\subsection{Qualitative Survey/Interview and Analyses}

Qualitative data collection is based on direct interview of twenty-seven participants within four categories that include professionals like town planners, architects and estate surveyor; chairmen of the artisans association like bricklayers, carpenters and iron benders; chairmen of the landlord association; and the secretary the local planning authority. There are two questions that were asked from the participants. The first question was related to why people live in area while the second question was related to the categories of people that are living in an area. These data was analysed using content analyses that involved the participants' opinion being illustrated and triangulated on their similarities and differences.

\subsection{Statistical Analyses}

The Statistical methods through the use of Statistical Package for Social sciences (SPSS) tool were employed to analyse the quantitative data. Correlation and regression analysis were drawn between the socio-economics variables and residential neighbourhood density. The presentation of results was through the use of simple descriptive statistics such as frequency tabulation and finding of percentage while histogram was used for illustration purposes. Simple statistical analysis was employed to explain the socio-economic factors as it affect the individual households' in the demand for residential neighbourhood.

\section{Data Analysis, Results and Discussion}

Cronbach's alpha was used to access the internal consistent reliability of the survey instrument. The Alpha value result is 0.646 which is considered sufficiently reliable. Hair, Black, Babin, Anderson, and Tatham (2006) and Peter and Denny (2012) claimed that scales with Cronbach's alpha of above 0.60 should be considered sufficiently reliable for an exploratory study such as this. The study also recorded higher respondents of 494 administered questionnaires with KMO value of 0.812 that signifies reliable, adequate and valid survey sampling (Field, 2000).

For the purpose of examining various categories of housing consumers in relation to the demand for residential neighbourhood within the study area, the understanding of their socio-economic background to have thorough knowledge of their social, economic, physical and cultural characteristics is highly important. This assisted in determining the capabilities of different housing consumers as it relates to the affordability of housing as well as their demands for residential neighbourhood. The socio-economic characteristics that were considered include the marital status, income earning group, educational level, employment status, official status, respondent's nativity, estimated monthly income and years living in Ibadan. Out of 500 questionnaires that were administered, 494 respondents completed their questionnaire. The analysis was therefore based on these 494 respondents.

\subsection{Demand for Residential Neighbourhood}

In addressing the first question, the investigation through interview discovered that there are various factors that contribute to the demand for residential neighbourhood by different housing consumers. These factors include accessibility to other towns such as Abeokuta, Lagos, Ijebu-Ode, expressway and so on, nearness to the place of work, offices of both the state and federal governments such as secretariat, NISER, UCH, location of tertiary institution such as Ibadan polytechnic and University of Ibadan, location of Government Reservation Areas (GRAs), offices, Inflow of people especially among youths from rural area to Ibadan in seeking for higher institution, job opportunity, business opportunity, to improve their economy status, for civilization to know what is going on in the society and nearness to the children school are the factors that make people prefer to reside within the five local government areas of Ibadan urban centre.

Ibadan urban centre is a commercially inclined with the presence of traditional and modern markets such as Oja-oba, Oritamerin, Agbeni, Owode academy, Dugbe, Alesinloye, Adamasingba shopping complex and the presence of central business district (CBD) that aids people to transact their business. The road networks pattern, cheap transport facilities for civil servant to go to their offices, cheap food, the peaceful nature of the city, good environment, favourable topography and security as well as other facilities such as pipe born water, less prone to crime and electricity are other factors that attract inflow of people to the Ibadan urban centre. 
On the second question, people living within Ibadan urban centre can be categorized according to their social class and these included low, medium and high income earners occupying high, medium and low density areas respectively. Though, population of low income earners is more than high income earners but every category can be found within the five local government areas. Each of the local government areas exhibits traditional core areas. High income earners are mostly found in low density estate whereas low income earners were found in the inner traditional high density core area within indecent houses that can be termed as traditional old buildings.

Majority of middle income earners decided to live in country side in non-decent and incomplete apartment. The socio-cultural value also plays a significant role in the demand for residential neighbourhood where people attached more value to family ties. This also contribute to the mixture of different socio-economic households living together in a neighbourhood except in GRA where the land and housing value is too high and unaffordable to low and middle income earners.

Correlation analysis drawn between the socio-economics variables indicates that there was strong relationship between Area Density (as measured by the Density scale) and socio-economics variables such as income earners, educational level, employment status, official status and estimated monthly income (as measured by their scale) using Pearson product moment correlation coefficient. Preliminary analyses were performed to ensure no violation of the assumptions of normality, linearity and homoscedasticity. There was a positive correlation among all these variables. Moreover, there was a strong, positive correlation between income earners and educational level variables $(\mathrm{r}=.58)$, between income earners and official status $(\mathrm{r}=.682)$ and between income earners and estimated monthly income $(\mathrm{r}=.853), \mathrm{n}=494, \mathrm{P}<.0005$, with high levels of education with high levels of official status, $\mathrm{r}=.580, \mathrm{n}=494, \mathrm{P}<.0005$, with high levels of education with high levels of income, $\mathrm{r}$ $=.605$, while relationship between employment status and official status is also positive with $\mathrm{r}=.630$ and between official status and estimated monthly income, $r=.693, \mathrm{n}=494, \mathrm{P}<.0005$. The relationship between area density and socio-economics variables are indicated in the Table 2. Compare the results of this correlation analysis among the socio-economics variables which determine the social class of different housing consumers indicates that, the social class of housing consumers influences the demand for residential neighbourhood.

Table 2. Correlation matrix analysis

\begin{tabular}{|c|c|c|c|c|c|c|c|c|c|}
\hline & $\begin{array}{l}\text { Area } \\
\text { Density }\end{array}$ & $\begin{array}{l}\text { Marital } \\
\text { Status }\end{array}$ & $\begin{array}{l}\text { Income } \\
\text { Earners }\end{array}$ & $\begin{array}{l}\text { Educational } \\
\text { Level }\end{array}$ & $\begin{array}{c}\text { Employment } \\
\text { Status }\end{array}$ & $\begin{array}{l}\text { Official } \\
\text { status }\end{array}$ & $\begin{array}{l}\text { Respondents' } \\
\text { Native }\end{array}$ & $\begin{array}{l}\text { Estimated } \\
\text { Monthly } \\
\text { Income }\end{array}$ & $\begin{array}{l}\text { Years } \\
\text { in } \\
\text { Ibadan }\end{array}$ \\
\hline Area Density & 1 & & & & & & & & \\
\hline Marital Status & .065 & 1 & & & & & & & \\
\hline Income Earners & $.271^{* *}$ & $.111^{*}$ & 1 & & & & & & \\
\hline $\begin{array}{c}\text { Educational } \\
\text { Level }\end{array}$ & $.310^{* *}$ & -.079 & $.576^{* * *}$ & 1 & & & & & \\
\hline $\begin{array}{l}\text { Employment } \\
\text { Status }\end{array}$ & $.171^{* *}$ & .066 & $.373^{* *}$ & $.421^{* *}$ & 1 & & & & \\
\hline Official status & $.266^{* *}$ & $.128^{* *}$ & $.682^{* * *}$ & $.580^{* *}$ & $.630^{* *}$ & 1 & & & \\
\hline $\begin{array}{l}\text { Respondents' } \\
\text { Native }\end{array}$ & .086 & -.032 & $.138^{* *}$ & $.227^{* *}$ & $.160^{* *}$ & $.161^{* *}$ & 1 & & \\
\hline $\begin{array}{l}\text { Estimated } \\
\text { Monthly } \\
\text { Income }\end{array}$ & $.287^{* *}$ & $.189^{* *}$ & $.853^{* * *}$ & $.605^{* *}$ & $.422^{* *}$ & $.693^{* *}$ & $.157^{* *}$ & 1 & \\
\hline $\begin{array}{l}\text { Years in } \\
\text { Ibadan }\end{array}$ & $-.110^{*}$ & $.195^{* *}$ & -.063 & $-.191^{* *}$ & $-.114^{*}$ & $-.117^{* *}$ & $-.399^{* *}$ & -.028 & 1 \\
\hline
\end{tabular}

At first, five predictors seemed to be significant. This has been elaborated in their relationship as explained above. To further ascertain how well the socio-economic factors is able to predict the demand for residential neighbourhood and which factors among all these factors is the best predictor(s), regression analysis was drawn using stepwise criteria as shown in Table 3 . The regression analysis result shows statistical significance of .000 which means $\mathrm{p}<.0005$. The implication of this result is that educational levels and estimated monthly incomes are the main predictors of the demand for residential neighbourhood among educational level, official status, estimated monthly income, income earners group and employment status. 
Table 3. Regression - variables entered/removeda

\begin{tabular}{|c|c|c|c|}
\hline Model & Variables Entered & $\begin{array}{l}\text { Variables } \\
\text { Removed }\end{array}$ & Method \\
\hline 1 & Educational Level & & $\begin{array}{c}\text { Stepwise (Criteria: Probability-of-F-to-enter }<=.010, \\
\text { Probability-of-F-to-remove }>=.100) .\end{array}$ \\
\hline 2 & Estimated Monthly Income & & $\begin{array}{c}\text { Stepwise (Criteria: Probability-of-F-to-enter }<=.010, \\
\text { Probability-of-F-to-remove }>=.100) .\end{array}$ \\
\hline
\end{tabular}

a. Dependent Variable: Area Density

\subsection{Socio-Economic Characteristics of the Respondents}

Table 4. Educational attainment level, employment status, official status, estimated monthly income and income earners group of the respondents

\begin{tabular}{|c|c|c|}
\hline \multicolumn{3}{|c|}{ Educational Attainment level of the Respondents } \\
\hline Educational level & Frequency & Percent \\
\hline No Formal Education & 51 & 10.3 \\
\hline Elementary Education & 360 & 72.9 \\
\hline Graduate & 67 & 13.6 \\
\hline Post Graduate & 16 & 3.2 \\
\hline Total & 494 & 100.0 \\
\hline \multicolumn{3}{|c|}{ Employment status of the Respondents } \\
\hline Employment status & Frequency & Percent \\
\hline Unemployed & 29 & 05.90 \\
\hline Self Employed & 346 & 70.00 \\
\hline Government Employee & 64 & 13.00 \\
\hline Company Employee & 38 & 07.70 \\
\hline Tertiary Institution/Research Employee & 08 & 01.60 \\
\hline Others & 09 & 01.80 \\
\hline Total & 494 & 100.00 \\
\hline \multicolumn{3}{|c|}{ Official Status of the Respondents } \\
\hline Official Status & Frequency & Percent \\
\hline Not Applicable & 387 & 78.30 \\
\hline Junior Staff & 48 & 09.70 \\
\hline Senior staff & 52 & 10.50 \\
\hline Management Staff & 07 & 01.40 \\
\hline Total & 494 & 100.00 \\
\hline \multicolumn{3}{|c|}{ Estimated Monthly Income of the Respondents } \\
\hline Estimated Monthly Income & Frequency & Percent \\
\hline Less than N10, 000.00 & 105 & 21.30 \\
\hline $\mathrm{N} 10,000.00-\mathrm{N} 30,000.00$ & 242 & 49.00 \\
\hline $\mathrm{N} 31,000.00-\mathrm{N} 50,000.00$ & 85 & 17.20 \\
\hline $\mathrm{N} 51,000.00-\mathrm{N} 75,000.00$ & 31 & 06.30 \\
\hline N76, 000-N90, 000.00 & 08 & 01.60 \\
\hline N91, 000-N120, 000.00 & 20 & 04.00 \\
\hline Above N120, 000.00 & 03 & 00.60 \\
\hline Total & 494 & 100.00 \\
\hline \multicolumn{3}{|c|}{ Income Earners Group of the Respondents } \\
\hline Income Earners & Frequency & Percent \\
\hline Low Income Earners & 432 & 87.4 \\
\hline Middle Income Earners & 39 & 7.9 \\
\hline High Income Earners & 23 & 4.7 \\
\hline Total & 494 & 100.0 \\
\hline
\end{tabular}

Source: Author's Survey, 2014 
The educational attainment levels of the respondents are grouped into four categories. These include no formal education, elementary education which comprises of those that obtained certificates from primary, secondary, modern, grade II and NCE/OND, the third category is graduate educational attainment level while MSc and PhD holders are grouped as Post graduate educational attainment level. Using this categorisation, the respondents that obtained elementary education takes the lion share with $72.90 \%$ of the total respondents followed by the graduate respondents with $13.60 \%$ while the respondents with post graduate level and no formal education are $3.2 \%$ and $10.30 \%$ respectively as shown in Table 4 .

Majority of the respondents $(70.00 \%)$ are self-employed. Only $13.00 \%$ and $07.70 \%$ are government and company employees respectively. $78.30 \%$ of the total respondents are not government workers. They engaged themselves in trading and artisan job. As a result of the nature of the category of this people, majority could not afford a decent house for living. Only $01.40 \%$ and $10.50 \%$ respondents constitute the management and senior staff.

Majority of the respondents $(49.00 \%$ of the entire sampled respondents) earn between N10, 000.00 and N30, 000.00 monthly followed by those that earn below N10, 000.00 which amount to $21.30 \%$. In view of this, majority of the respondents are within the low income population. $17.20 \%$ and $06.30 \%$ earn between N31, 000.00 and N50, 000.00 and between N51, 000.00 and N75, 000.00 respectively.

Those that are earning between N76, 000.00 and N90, 000.00 and between N91, 000.00 and N120, 000.00 are $01.60 \%$ and $04.00 \%$ respectively while only $0.6 \%$ of the respondents are earning above N120, 000.00 . In spite of the low income of the respondents, the survey reveals that majority of the respondents are not engaging in any other occupation that can bring them addition income. $93.70 \%$ of the respondents have no other source of income while only $06.30 \%$ claimed to have additional source of income to their primary employment.

Estimated monthly income is used to group the respondents into Low income, Middle income and High income earners. The respondents that earn below N50, 000.00 are grouped as low income earners, those that earns between N51, 000.00 and N90, 000.00 are grouped as middle income earners while the respondents that earn up to N91 and above are grouped as high income earners. The grouping was made in accordance with Nigerian National Housing Policy (FGN, 2004) definition of income earners. On the basis of this grouping, majority of the respondents are low income earners with $87.40 \%$ followed by the middle income earners with $7.90 \%$ while the least is high income earners with $4.70 \%$ of the total respondents.

Educational level and estimated monthly income reflected in employment and official status as shown in Table 4 and Figure 1.

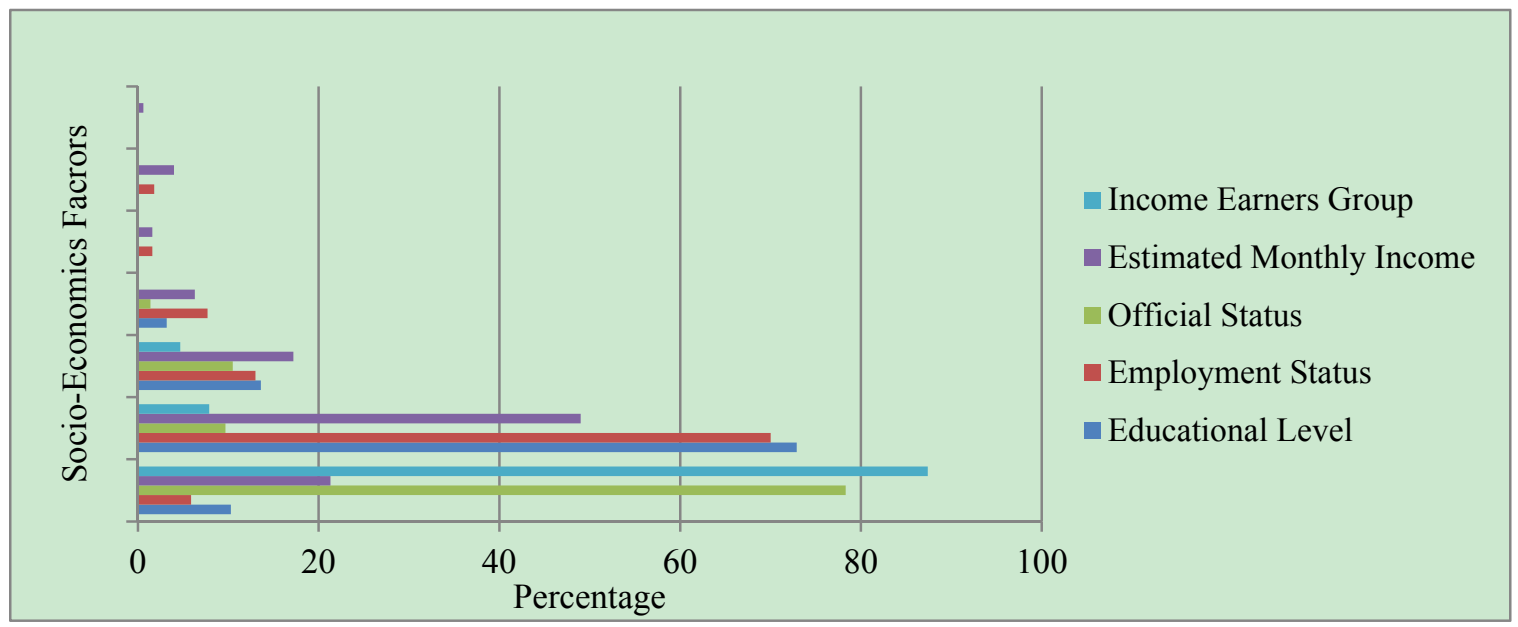

Figure 1. Socio-Economic Variables

Source: Author's Survey, 2014

\section{Findings}

In this article, quantitative and qualitative approaches were used to explore the influence of socio-economic factors on the demand for residential neighbourhood. The results of the quantitative survey revealed that the educational level of the majority of the respondents are low and this reflects in their income level, employment status, official status and their income group as well as the type of housing and the neighbourhood they live in. 
The employment status of the respondents also reflected higher proportion of the respondents that are not government workers and their estimated monthly income as well as their official status. Majority engaged themselves in trading and artisan jobs. The official status of the respondents reflected that greater proportion of the respondents can be categorised as the low income earners. They cannot afford high priced house rents or decent house for living. This suggests the type of housing majority households occupy and the neighbourhood where they reside. Majority could not afford a decent house either as rented or personal house for living. The senior and managerial staffs are the only housing consumers that can afford decent housing for living. This shows the effect of low income of the households on the affordability of decent housing and the type of neighbourhood they are living within the study area. The low income of the majority of the housing consumers dictates the housing preference and the residential neighbourhood.

The educational level and estimated monthly income of the housing consumers are therefore discovered to be the major determinants of the housing preference and demand for residential neighbourhood within Ibadan urban centre. This could be the reason why individuals or families with high educational background avoid residing where people of low educational background or income earners live. Family or individual with high educational background are rational in thinking. Educational development makes people to be conscious of their status or to have sense of status with development of pride which does not allow them to make decision on demand for residential neighbourhood anyhow. In other word, economic and education make people concern about their lifestyle.

There is a strong correlation between the socio-economic indicators and educational level. This shows that high education ensures higher economic status. Economy proves affordability but education adds to the value of lifestyle. Better lifestyle is correlated with low density. But as majority of people belong to low income group with low education, thus not only they cannot afford better lifestyle, but also may not be aware of better lifestyle. Therefore, better education is the key to improve awareness and affordability for a better lifestyle.

The results of qualitative approach performed with twenty-seven participants revealed that people of high social class prefer to live within the low density area in order to associate themselves with enlightened and educated people like themselves. Whereas the low income people with low educational background prefer to live in high density area as a result of their socio-economic status which cannot cope with the high priced housing within the low and decent environment. People of middle level prefer to go to the countryside where the rent can be affordable and the environment is fairly okay to them.

This study concludes that the demand for residential neighbourhood in Nigerian urban centres with particular reference to Ibadan is determined by socio-economics status of housing consumers. The socio-economics factors that strongly relate to the demand for residential neighbourhood include the educational level, employment status, official status and monthly income while respondents' nativity and years of their living in Ibadan are weakly related. However, educational level and estimated monthly income are the major determinants.

This supported the view of Datal and Bonaccio (2010) that consumer's preference and his social support to choose the right alternatives and recommendation is the key to a successful and correct decision. Housing consumers are expected to make a judicious decision particularly when it is of such a high value that can impact their social, psychological and financial life. Housing consumer's social position influences on their abilities to make better decision on housing demand and the demand for residential neighbourhood.

\section{Conclusion}

This study concludes that the demand for residential neighbourhood in Ibadan urban centre is determined by the socio-economic status of individual household. The findings revealed educational level and estimated monthly income of the housing consumers are the major determinants factors that influence the demand for residential neighbourhood of housing consumers in Ibadan urban centre while others include employment and official status. The nativity, years of living in Ibadan and the socio-cultural value of the respondents has weak influence. In a wider sense, Low and middle income households are more likely to choose residential neighbourhood that are less priced based on their socio-economics status. These categories of housing consumers are mostly found in a slum and indecent environment. Some decided to be living in an uncompleted housing unit which does not enhance their safety and comfort. On the other hand, the high income household prefer to live in a well laid out environment in order to interact with high educated and social class because their socio-economics status.

Many efforts have been made by Nigerian government of different regimes to make provision for decent housing for people; all the strategies being adopted so far have not yielded much fruit due to the fact the socio-economics status of the housing consumers have not been taking into consideration. This study implies that any future planning and development of housing provision for Ibadan and Nigerian urban centres as a whole should 
consider consumers' socio-economics status and get housing consumers with different socio-economics status starting involved in the planning, development and implementation of housing program.

It will be possible to achieve appropriate and sustainable housing provision for Nigerian masses and prevent some of the implementation shortcomings of the present public housing programs in Nigeria. In consideration of this aim, the present study is an attempt to move beyond measuring the demand for residential neighbourhood by socio-economics factors in Ibadan urban centre and to apply this framework to different urban centres within Nigeria.

\section{Acknowledgments}

The authors sincerely acknowledge the Research Management Center (RMC) of the Universiti Teknologi Malaysia (UTM), and the Ministry of Education (MOE) of the Government of Malaysia for the funding of the research through research grant no. 4L063, 07H37, 4S104.

\section{References}

Ademiluyi, A. I. (2010). Public Housing Delivery Strategies in Nigeria: A Historical Perspective of Policies and Programmes. Journal of Sustainable Development in Africa, 12(6), 153-161, Clarion University of Pennsylvania, Clarion, Pennsylvania.

$Æ r \oslash$, T. (2006). Residential Choice from a life style Perspective. Housing, Theory and Society, 23(2), 109-130. http://dx.doi.org/10.1080/14036090600773139

Agbola, T. (1987). Institutional Constraints on Housing development. Habitat International, 11, 113-120. http://dx.doi.org/10.1016/0197-3975(87)90061-0

Agbola, T. (1998). The Housing of Nigerians: A Review of Policy Development and Implementation. Research Report, 14. Development Policy Centre, Ibadan.

Agbola, T., \& Adegoke, S. A. (2007). Economics in Housing. In T. Agbola, L. Egunjobi, \& C. O. Olatubara (Eds.), Housing Development and Management. A book of readings (pp. 107-149). Department of Urban and Regional Planning, Faculty of Social sciences, University of Ibadan, Nigeria.

Agbola, T., \& Kassim, F. (2007). Conceptual and theoretical issues in Housing. In T. Agbola, L. Egunjobi, \& C. O. Olatubara (Eds.), Housing Development and Management. A book of readings (pp. 15-69). Department of Urban and Regional Planning, Faculty of Social sciences, University of Ibadan, Nigeria.

Ajanlekoko, J. S. (2001, October 2-5). Sustainable Housing Development in Nigeria: The Financial and Infrastructural Implication. International Conference on Spatial Information for Sustainable Development at Nairobi, Kenya.

Akintunde, K. O. (2008). Housing Needs and Land Administration in Nigeria: Problems and Prospects. Social Research Network. In I. O. Smith (Ed.), Land and Real Property Rights in Nigeria.

Arimah, B. C. (1997). The determinants of housing tenure choice in Ibadan, Nigeria. Urban Studies, 34(1), 105-124. http://dx.doi.org/10.1080/0042098976294

Aweto, A. O. (1994). Soils. In M. O. Filani et al. (Eds.), Ibadan Region. Nigeria: Rex Charles Publishers.

Ayeni, M. O. A. (1994). The metropolitan area of Ibadan: its growth and structure. In M. O. Filani et al. (Eds.), Ibadan Region. Nigeria: Rex Charles Publishers.

Birrell, \& Healy, E. (2003). Migration and Housing Affordability Crisis. People and Place, 11(3), 43.

Birrell, B., O’Connor, K., Rapson, V., \& Healy, E. (2005). Melbourne 2030: Planning Rhetoric Versus Urban Reality. Monash University Press, Melbourne.

Chuma, J., \& Molyneux, C. (2009). Estimating inequalities in ownership of insecticide treated nets: Does the choice of socio-economic status measure matter? Health Policy and planning, 24(2), 83. http://dx.doi.org/10.1093/heapol/czn050

Datal, R., \& Bonnacio, S. (2010). What types of Advice do Decision-Makers Prefers? Organisational Behaviour and Human Decision Processes, 112(1), 11-23. http://dx.doi.org/10.1016/j.obhdp.2009.11.007

Department of Sustainability and Environment, Victoria - DSE. (2003). Urban Development Program Report 2003. Government of Victoria, Melbourne.

Edward, L. G. (2010). The Death and Life of Cities. Harvard University and Nber.

Federal Government of Nigeria-FGN. (2004). National Housing Policy Draft, Abuja. 
Field, A. (2000). Discovering Statistics Using SPSS for Window. London: Sage.

Glaeser, E. L., Kahn, M. E., \& Rappaport, J. (2008). Why Do the Poor Live in Cities? The Role of Public Transportation. Journal of Urban Economics, 63(1), 1-24. http://dx.doi.org/10.1016/j.jue.2006.12.004

Glaeser, E., \& Ward, B. (2009). The Causes and Consequences of Landuse regulation: Evidence from Greater Boston. Journal of Urban Economics, 65(3), 265-279. http://dx.doi.org/10.1016/j.jue.2008.06.003

Glaeser, E., Kolko, J., \& Saiz, A. (2001). Consumer city. Journal of Economic Geography, 1, 27-50. http://dx.doi.org/10.1093/jeg/1.1.27

Gregory, C. C., \& Linlin N. W. (2009). Demand and Supply for Residential Housing in Urban China. Unpublished monograph. Princeton University and Xiamen University, August.

Guido, W. I., \& Tony, L. (1996). Efficient estimation and stratified sampling. Journal of Econometrics, 74, 289-318. http://dx.doi.org/10.1016/0304-4076(95)01756-9

Gurran, N., Ruming, K., Randolph, B., \& Quintal, D. (2008). Planning, Government Charges, and the Cost of Land and Housing. AHURI Positioning paper no. 109, Australian Housing and Urban Research Institute (AHURI).

Hair, J. F., Black, W. C., Babin, B. J., Anderson, R. E., \& Tatham, R. L. (2006). Multivariate data analysis. Upper Saddle River, NJ: Pearson Education.

Hoek-Smit, M. C., \& Diamond, D. B. (2003, March 10-13). The Design and Implementation of Subsidies for Housing Finance. Washigton DC: Prepared for the World Bank Seminar on Housing Finance, Washigton DC.

Huws, U. (2002). Towards a Definition of Socio-Economic Research for the Respect Project. A Draft Working Paper.

Ikejiofor, U. (1998). Tyranny of inappropriate Policies: Sharing as Housing Strategy among middle /low-income Households in Abuja, Nigeria. Cities, 15(16), 429-436. http://dx.doi.org/10.1016/S0264-2751(98)00038-9

Israel, A. A., \& Bashiru, A. R. (2008). Public and Private Developers as Agents in Urban Housing Delivery in Sub-Saharan Africa: the Situation in Lagos state. Humanity and Social Sciences Journal, 3(2), 143-150.

Jabareen, Y. (2005). Culture and Housing Preferences in a Developing City. Environment and Behaviour, 37(134). http://dx.doi.org/10.1177/0013916504267640

Jun, M. T. (2006). The Effects of Portland's Urban Growth Boundary on Housing Prices. Journal of the American Planning Association, 72(2), 239-243. http://dx.doi.org/10.1080/01944360608976742

Key, R. J., \& Firebaugh, F. M. (1989). Family resource management: preparing for the 21 st century, Journal of Home Economics, 81(1), 13-17.

Mehdi, Y., Laily, H. P., Mumtazah, O., \& Turiman, S. (2009). Factors Affecting Family Economic status. European Journal of Scientific Research, 37(1), 94-109.

Mehta, A. C. (1997). Population Projections: Sub-National Dimensions. Commonwealth Publishers, New Delhi.

National Population Commission-NPC. (1963). Nigeria Population Commission Official Report of 1963 Population Census Figures. Abuja: Federal Government of Nigeria.

Nelson, A., Dawkins, C., \& Sanchez, T. (2007). The Social Impacts of Urban Containment. Aldershot, Hampshire.

New Zealand Institute of Economic Research. (2005). Quarterly Predictions. Sept., Wellington, New Zealand Institute of Economic Research, Issue 163.

NPC. (1991). Nigeria Population Commission Official Report of 1991 Population Census Figures. Abuja: Federal Government of Nigeria.

NPC. (2006). Nigeria Population Commission Official Report of 2006 Population Census Figures. Abuja: Federal Government of Nigeria.

Okechukwu, J. N. (2009). Urban Housing Affordability and Housing Dilemmas in Nigeria (Unpublished doctoral dissertation). University of Birmingham, Centre for Urban and Regional Studies, School of Public policy, The University of Birmingham.

Olatubara, C. O. (2007). Fundamentals of Housing. In T. Agbola, L. Egunjobi, \& C. O. Olatubara (Eds.), Housing Development and Management: A Book of Readings (pp. 70-106). Department of Urban and 
Regional Planning, Faculty of Social Science, University of Ibadan, Nigeria.

Olayiwola, L. M., Adeleye, O., \& Ogunshakin, L. (2005). Public Housing Delivery in Nigeria: Problems and Challenges. World Congress on Housing Transforming Housing Environments Through the design. Pretoria South Africa, 33. IAHS.

Onibokun, P. (1985). Housing in Nigeria, A book of Readings. Nigerian Institute of Social and Economic Research (NISER), Ibadan.

Onu, V., \& Onu, A. J. C. (2012). Urban Residential Housing and Low-income Earners: A study of Makurdi Metropolis, Benue state, Nigeria. European Scientific Journal, 8(28), 231-246.

Peter, N., \& Denny, M. (2012). The Determinants of Urban Resource Consumption. Environment and Behavior, 44(1), 107-135. http://dx.doi.org/10.1177/0013916510390494

Quigley, J. (2003). Transaction Costs and Housing Markets. In T. O'Sullivan \& K. Gibb (Eds.), Housing Economics and Public Policy. Oxford, Blackwell Sciences/RICS Foundation.

Roback, J. (1982). Wages, Rents and the quality of life. Journal of political Economy, 90, 1257-1278. http://dx.doi.org/10.1086/261120

Tatu, M. L. (2010). Exploring Social-Cultural Explanations for Residential locations Choices: The case of an African City-Da es Salaam. KTH Vetenskap OCH Konst, KTH Architecture and the Built Environment. (Doctoral dissertation), Built Environment Analysis Stockholm, Sweden, Royal Institute of Technology, school of Architecture and Built environment, department of Urban Planning and Environment Built Environment Analysis, Stockholm, Sweden, Published in Sweden by the Royal Institute of Technology.

Tipple, G. (2001). The Impact of Regulations on the livelihoods of people living in poverty. Retrieved from http://www.Itdg.Org/docs/shelter/g\%20tipple\%20case\%20study.Doc

Todd, S. (2007, March 8). Urban Housing Demand, prepared for the new Palgrave Dictionary of Economics. University of Pennsylvania (Wharton) and NBER, Edited version.

Tomori, M. A. (2007). Ibadan Metropolitan Area and the Challenges to Sustainable Development (Unpublished Monograpgh).

Welsh, A. (2002). Local Housing Market Analysis: An advice note to Welsh Local Authorities from the Welsh Assembly Government. Cardiff: Housing Strategy Branch, Welsh Assembly.

Winstanley, A., Thorns, D. C., \& Perkins, H. C. (2002). Moving House, Creating Home: Exploring Residential Mobility. Housing Studies, 17(6), 813-832. http://dx.doi.org/10.1080/02673030216000

Zukins, S. (1988). Loft Living: Culture and Capital in Urban Change. London: Radius.

\section{Copyrights}

Copyright for this article is retained by the author(s), with first publication rights granted to the journal.

This is an open-access article distributed under the terms and conditions of the Creative Commons Attribution license (http://creativecommons.org/licenses/by/3.0/). 